報 告
日本歯科医学会プロジェクト研究費平成 24 年度採択研究事業報告概要

\author{
歯や咬合支持が高齢者の健康に及ぼす影響に関する \\ 多施設参加型大規模疫学研究 \\ 服部佳功（東北大学）
}

\section{Multi-center large-scale epidemiological study on the effects of dental and occlusal support status on the health of the elderly populations}

\author{
Yoshinori Hattori, DDS, PhD
}

\begin{abstract}
研究結果概要
高齢者の歯や咬合支持が健康に及ぼす影響を明らか にする意義は大きいが，多数の被験者を要するこうし た研究を単独の施設が実施するには困難が多く，多施 設参加型大規模疫学研究の推進が不可欠である. 多施 設参加型研究では，施設間で記録や評価の均質性が保 障されねばならない，歯や咬合支持と健康の関連を検 討する多施設参加型疫学研究を計画する際, 健康指標 や評価基準の選択は最重要の検討課題に含まれる。本 研究では, 今後行われるべき多施設参加型研究のデザ イニングに向け，アウトカムである健康指標について 考察した。

健康や疾病に係る医学的評価指標の記録が困難な場 面で，しばしば代替指標に用いられるのが健康関連 QOLである。医療現場におけるQOL 重視を反映した ものであるとともに，手間や経費の掛かる医学的評価 を回避する意図もあろうかと察せられるが，包括的尺 度にせよ疾患特異的尺度にせよ, 健康の主観的評価で ある QOL が健康や疾病の客観的評価に代わりうるも のではない。一方，本邦における高齢者保健の主要な 目標が，日常的介護を要せず，自立した生活ができる 状態を維持することであり, 長寿より健康寿命の延伸 が求められていることを考えるならば，要介護状態の 発生 (要介護発生)をもつて健康喪失の代替指標と捉え,
\end{abstract}

それをアウトカムとする研究を計画することに，一定 の妥当性を見出しうると考えられる。要介護発生をア ウトカムとすることには, 要介護認定が公的介護保険 制度下で一定の基準に基づいて下されるものであるこ とや，居住地の自治体から情報を入手可能であること などの利点があり, 多施設参加型研究に好適なアウト カムであると考えられた。

一方, 歯や咬合支持と要介護発生の関連に着目して 実施された研究は, 論文 1 篇, 学会報告 1 篇の 2 篇に 過ぎず，両者のデザインは著しく異った。 今後の研究 計画の策定では，説明変数の概念，測定方法，評価方 法の適切な選択が必要と推察された。

研究代表者：佐々木啓一（東北大学）

分担研究者: 池邊一典 (大阪大学), 服部佳功 (東北大 学)

\footnotetext{
著者連絡先 : 服部 佳功

干 980-8575 宮城県仙台市青葉区星陵町 4-1 東北大学大学院歯学研究科口腔機能形 態学講座加齢歯科学分野 Tel\&Fax: 022-717-8396

E-mail: yoshinori.hattori.b4@tohoku.ac.jp
} 
Multi-center large-scale epidemiological study on the effects of dental and occlusal support status on the health of the elderly populations

Keiichi Sasaki ${ }^{\mathrm{a}}$, Kazunori Ikebe ${ }^{\mathrm{b}}$ and Yoshinori Hattori ${ }^{\mathrm{a}}$

${ }^{\mathrm{a}}$ Tohoku University, ${ }^{\mathrm{b}}$ Osaka University, 